\title{
Individualism, life trajectories and plans of constituting a family
}

\author{
Individualismo, trajetórias de vida \\ e projetos de constituir família
}

\author{
Carolina de Campos BORGES \\ Andrea Seixas MAGALHÃES ${ }^{2}$
}

\begin{abstract}
The present paper discusses the results of a research that had as its main purpose to analyze the life projects of individuals belonging to different generations within the last decades, with special emphasis on the role played by establishing a family in such projects. Speeches of 20 individuals (10 men and 10 women) from two generations were analyzed. The study pointed out that the profound contemporary sociocultural changes have led to increasing individualism in the relationships, and consequently have altered the way people engage in building their life courses. Two things have been occurring simultaneously. On the one hand, life courses are being individualized and previous standards are being broken, a phenomenon linked to the reduction of gender asymmetries and to the questioning of the institutions. On the other hand, the family model based on marital stability is being repelled. Due to the instability of love relationships, children are gaining importance in the structuring of the idea of a family.
\end{abstract}

Uniterms: Family; Individualism; Life course.

\section{Resumo}

Este trabalho discute resultados de uma pesquisa cujo propósito foi analisar os projetos de vida de indivíduos de diferentes gerações nas últimas décadas, atentando especialmente para o lugar que constituir uma família ocupa em seus planos. Foram analisados os discursos de 20 sujeitos de duas gerações, 10 homens e 10 mulheres. O estudo indicou que as intensas mudanças socioculturais contemporâneas levaram ao aprofundamento do individualismo nas relações e, consequentemente, à alteração nas formas de engajamento dos indivíduos na construção de suas trajetórias de vida. Vem ocorrendo, por um lado, a individualização e a despadronização das trajetórias de vida, associada à diminuição das assimetrias de gênero e ao questionamento de instituições; e, por outro lado, vem ocorrendo a desestruturação de um modelo de família baseado na estabilidade do casamento. Diante da instabilidade das relações amorosas, filhos passam a ter uma importância cada vez maior na estruturação da ideia de família.

Unitermos: Família; Individualismo; Trajetória de vida.

\section{$\operatorname{coth}$}

- Universidade Federal do Grande Dourados, Curso de Psicologia. Dourados, MS, Brasil.

2 Pontifícia Universidade Católica do Rio de Janeiro, Departamento de Psicologia. R. Marquês de São Vicente, 225/201L, Gávea, 22451-900, Rio de Janeiro, RJ, Brasil. Correspondência para/Correspondence to: A.S. MAGALHÃES. E-mail: <andreasm@puc-rio.br>.

Article based on the doctorate thesis of the C.C. BORGES, intitled "Permanências e mudanças: individualismo, trajetórias de vida efamilia" Pontificia Universidade Católica do Rio de Janeiro, 2011. Support: Coordenação de Aperfeiçoamento de Pessoal de Nível Superior. 
Many important changes have occurred, over the last decades, in the way a lot of happenings connected to the universe of the family, such as births, marriage and death, are experienced. Instituto Brasileiro de Geografia e Estatística (IBGE, Brazilian Institute of Geography and Statistics) and Instituto de Pesquisa Econômica Aplicada (IPEA, Applied Economic Research Institute) data point out, for example, a significant decline in birth rates, a rise in life expectancy, the older age at which men and women get married, as well as a rise in the number of marriages (such rise is due to the legal informal unions acknowledgement, cohabitation of spouses without a civil registration union), a rise in the number of divorces, a rise in the number of families headed by women and a rise in the number of children born outside formal marital relationships.

Those changes are related to family life and to people's life paths, simultaneously. After all, why did people, up to a few decades ago, get married at a younger age, got divorced less, and men were the usual breadwinner? What do these changes mean concerning the relations established within a family?

As Bauman (2008), Giddens (2003) and Hall (2001) point out, the present changes have been causing a transformation in the feelings attributed, by individuals, to relationships. In a world characterized by the grater scope of individuals on their lives and identities, new meanings have been attributed to family relationships.

Based on these questions, a research focused on investigating the transformation process of the life projects of individuals of two generations in Rio de Janeiro (RJ), Brazil, was developed. The understanding, mainly of how the idea of starting a family links to life projects was sought.

The results of such investigation are discussed in this article. They have showed that the desire to get married, to have children, to start a family, as well as the way a family is conceived, are articulated to what is presented as a model of life paths for people in each social context. Therefore, the idea of conceiving a family seemed different to people of each generation. Among the older people who were interviewed, the concept of family based on the existence of a stable couple was shared. As for the younger people who were interviewed,

178 their concepts of family are based on the existence of children. That does not mean that children did not play a fundamental role in a family. What has changed was especially the relationship between "having children" and "marriage". For the older generation children were the result of a project of the couple. For the younger generation, many times, children are the result of private projects.

It is also discussed in this article that each of these concepts of family - the family centered on the couple and the family centered on the children -, is related to a socially produced life path. The high level of individualization of life paths that characterize contemporaneity creates an unbalance to the family conception that had the couple as the core, for the vulnerabilities that reach the individual also affect the family universe.

The relationship between individualism and the emergence of new concepts of family nowadays, is an issue that has been discussed in many studies. Authors such as Attias-Donfut, Lapierre and Seagalen (2002), Kaufmann (2007a), Seagalen (2008) and Singly (2007), in France, Carvalho (1995), Féres-Carneiro and Ziviani (2009), Féres-Carneiro (2005), Féres-Carneiro, Ziviani and Magalhães (2011), Figueira (1987) and Jablonski (1998; 2009; 2010),

Rocha-Coutinho (2005), Vaitsman (1994), Wagner (2002), among others in Brazil, have dedicated themselves to the issue of knowing what family can exist within the context of individualization of life paths. This issue will be revisited here, through the data that emerged in this study.

\section{Method}

This research was conducted according to the premises of discourse analysis. According to RochaCoutinho (1998), discourse analysis has its origins in the field of linguistics, but it is interesting to psychology when the purpose is to perform psychosocial studies. This methodology was considered adequate for the carrying out of this research, once it was our objective to learn the lines of the subjects as texts produced within a socio-cultural context and exploit the underlying ideological systems.

Some semi-structured interviews with 20 people were held, 10 people belonging in the older generation 
(ages ranging from 63 to 69), and 10 people in the younger generation, (ages ranging from 27 to 34), half men, half women, all Rio de Janeiro middle-classed residents of the southern neighborhoods. The age groups were defined because of the objective to confront the experiences of people from different generations, taking into consideration that it is an interesting way to grasp social changes (Mannheim, 1982).

The research subjects' choice happened according to the following criteria:

They should belong to different social groups, have been born in Rio de Janeiro (RJ) or lived there most of their lives. No other condition, such as marital status, living with the family or not, having children etc., was previously established. However, it is noteworthy that the recurrence of single and childless people within the generation of 25 to 35 years old may have influenced the results that were obtained in this study.

The subjects of this research were invited to participate in a survey from their social network. This is a recruiting strategy that according to Heilborn (2004), is used to have access to a minimally controlled material, when middle classes are targeted, an extremely vast and varied segment, difficult to be defined. It is about an attempt to approach people who share a close representation of the world within the "middle classes", making the comparison of their discourses possible.

The script for the interview was made in a way that unforeseen information would not be allowed to emerge. The interviewees were invited to talkfreely about their life projects - concerning the people from the older generation, it was sought to know the life projects they had when they were younger, while young generation interviewees were asked about their present life projects. The interviews were recorded in mp4 files, and later transcribed in full. The resulting texts were submitted to discourse analysis.

The analysis of the interviews was influenced by Comprehensive Sociology (Kaufmann, 2007b) concerning the thin articulation between the fieldwork made and the emersion of the analysis categories. It was a type of study in which what is being studied is not the objectivity of the data, but the interpretation of the interviews produced by the researcher.
Before being interviewed, all the interviewees signed a Statement of Consent, in which they expressed agreement in participating in this study and authorized the use of information for academic purposes and publishing, and the researcher is committed to ensuring the confidentiality of their identities and use fictitious names in the dissemination of results. This study was granted with the approval of the Research Ethics Committee of the University.

\section{Results and Discussion}

The survey showed that, closely linked to the deepening of individualism in a contemporary social setting, there has been a weakening of the concept of family centered on the couple and the emergence of the concept of a family centered on children. More emphasis has been put on the parent-children relationship than on the ties of a couple in the ways of conceiving a family to be formed, as shown in the words of the interviewees:

... Children, I would like to have them. Maybe 5. I wish I had
had them... With a partner. The right partner. But then,
with children, I was already going to get married. I would
want to marry and start a family, right? To have a
traditional family. I believe that a couple has to raise their
kids together, stay together, watch the children grow up
together (Antônia, 63 years old, single). Ok. The plan to have a family has always existed. I've always wanted to have children... . Children. Family. A husband? No. I mean, if there is a husband, it's 100\% better because it will be the character who will help me take care of the family (Lígia, 33 years old, single).

The discourses of those two women, from different generations, Antônia and Lígia, clarify two very different concepts of family, in which the centrality of marriage to what a family represents is at stake. The words of Antônia (63), takes us to a concept of family founded at marriage. "Traditional family" actually is that kind of family formed around the core of marriage. That is the family concept which Segalen (2008) talks about, where the couple founded the modern family. Therefore, the children would be part of the Family, but would only come after the consolidation of the matrimony, and were the result of the projects of the couple. 
Such family concept directly reflects the influence of modern values on the mentality and speeches of this generation. Within this concept, marriage core results from a formal marriage. It can be noticed through the distinction that Antônia makes between "partner" and "someone to marry". "With a partner. With the right partner. But then, with a child, I was already going to get married". So, her discourse demonstrates that it would be important for her that a formal marital relationship existed according to the institutional laws of the time.

The appreciation of the legal formalization of the marital relationship is directly linked to the expectation of long-term marriage. This is an aspect that Antônia's discourse highlights. In a modern concept of family, the idea of solidity and durability of the marital relationship is present. "Staying together, watching the children grow up together" indicates the existence of an expectation that the marriage will last for many, many years-another characteristic of the modern family (Segalen 2008; Singly, 2007).

As for Lígia, the idea of starting a family focuses, first of all, on the plan to have children. Marriage stops being a sine qua non condition in the constitution of a family, which once more takes us to Segalen (2008), who states that on the verge of divorce, nowadays, it is the child who founds the family.

Therefore, we notice an important transformation in the concept of family from the previous decades, founded around marriage (Féres-Carneiro \& Ziviani, 2009).

Currently, it is possible to imagine a family without a couple, only with children, and also accept that children are born outside a stable relationship. Furthermore, children are no longer the exclusive result of couples' projects and also become the results of individual projects.

It is advisable to notice that even though Lígia does not mention the "right family" model - the "happy family", centered on the couple - whenever she considers having children, she refers to the benefits that the existence of a husband could bring."If there is a husband, it is 100\% better, because he will be the character who will help me take care of the family". 100\% better is not the same as $10 \%$ or $50 \%$ better. It is actually a meaningful number that could indicate that her modern discourse hides a paradoxical appreciation of a traditional reference. This contradiction also appears when she uses the word "husband" to take care of the Family. It shows that life path and family patterns do not change linearly in time, but as they start incorporating new values and joining old references, which is not done without paradoxes or contradictions.

The analysis has turned, then, into the comprehension of each of these families concept meaning, front to the appreciation of their interrelations with broader social changes. Among such changes stands the individualization of nowadays men and women's life path models.

It was noticed, through the research done, that the idea of making "life projects", frequent to the universe of people from older generations, has been replaced by the idea of "not having definite future plans" when it comes to people of younger generations, as shown below:

... at that time, life projects included a professional life and a family... Society would impose these things and we were supposed to do what was culturally expected from us. It was really hard. Afterwards, there was this whole rebellion, dissatisfaction and the whole, "how about individual freedom?' thing (Elias, 65 years old, separated).

I was already dating my boyfriend, who has been my husbandfor 5 years... I don't know... it was, like, something that I was supposed to do, you know, getting married. Then I got married because I thought it was a consequence of life when I got to that age... (Gilda, 65 years old, separated).

The future plan that I have is my private retirement... So, I don't plan a lot, like, what I'm going to be doing in 10 years. I don't want to know about 10 years from now (Flávio, 31 years old).

I don't worry today about future preoccupations that I may have, but I have nothing planned, like. I'm going to do that... . Because I think... things, good or bad, happen.... And there isn't much you can do in situations like these... (Paula, 31 years old).

The analysis of the discourse of the interviewees has also shown that in response to the advance of individualism in society, there is a decrease in the asymmetries alike. A larger proximity between the universes of men and women, and the replacement of 
the family as the core of projects and people's life paths is evident.

For people of older generations the distinction between the male and female social roles was very clear. Men were assigned with the responsibility for affairs of public sphere, and for being the breadwinners, while women were in charge of domestic life organization:

I only got married when I thought I had conditions to effectively support my family, all by myself... all the subsistence, I always thought it was my exclusive responsibility, all things regarding my wife and kids (Augusto, 66 years old, married for the $2^{\text {nd }}$ time).

... (work) had some importance because I could make myown money, even if it was little... . But my work revolved around my boys'schedule. My priority was my boys. Then, for example, if they studied in the afternoon, I would work in the afternoon... Anything they wanted... Them, the house, the husband, the whole ironing thing, that's what I was responsible for Haha (Francisca, 65 years old, separated).

In the discourses of the interviewed people of the younger generation, there was more similarity between men and women's speeches of this generation, and their concerns and desires were more similar. Nowadays, men and women tend to be equally worried about their financial independence and about their professional achievements as shown below:

Well, I'm in a social class... middle class... . So we have a certain difficulty, how can I say... to progress and grow in life... . Difficulties, I mean, in terms of work. It's a very tough competition; it's hard to get a nice place to work, making some good money, having your own space... It's so hard! It isn't easy today (Flávio, 31 years old, single).

... I graduated, and when we graduate we expect to get a good job in our areas fast... I have been working at this job, but it isn't exactly what I want.... Then, my main worry at the moment is to be financially stable and maybe find ajob in which / can feel professionally satisfied.... Who said that we work in order to get money to have fun? No, sometimes we work only to make a living, you know? (Lígia, 33 years old, single).

Therefore, one can notice that men and women of a younger generation were committed to work and aimed at financial independence. For the men of another generation, that was already embedded in their concerns, but not for the women. Women's ambition regarding formal work is something relatively new within the Brazilian culture, and leads to the weakening of a pattern that is strongly incorporated to our society, in which women were destined to be mother-wife, financially dependent on the husband, who corresponded to the "breadwinner-men and housewife-woman" model (Costa, 1989; Maluf \&Mott, 2008; Rocha-Coutinho, 1994).

Our research has indicated that on one hand, nowadays women have conquered a new realization space - the world of work -, and men have also started to find a very important place for their personal realization in life inside the house. Reconciling work and family has been considered, even though it does not necessarily mean a change in relation to the sharing of the housework.

Ah, I would really like to have time for my wife and kids, travel with them, and at the same time I have to work so hard preparing classes for two courses... maybe you can't be the professional you want to be and the father you would like to be. I think this is it... to be present, right? To talk to your wife and kids. To watch TV together and ask what they have been doing, to know about their lives, if they're having trouble in school, if they're dating, if they're not dating... to participate, to give opinions, something I don't like to do very much, but that must be done. I don't know... To give them good examples, to be honest with them... . I think this is it (Gabriel, 27 years old, single).

According to Gabriel's discourse, participating in Family life is mostly about the desire to participate in the children's life - by talking, watching television together, wanting to know more about their lives - and setting a good example to them. In this speech, the idea of conciliating work and family has a meaning of emotional opening to a universe, previously exclusive to women. Conciliating work and family cares will mean to be able to be emotionally present in the lives of the children and the wife, enjoy a coexistence that was not valued by men in the past.

As long as financial independence and professional realization become part of a world of women, and being emotionally present in the life of the family starts being considered important to men, a meaningful transformation in social patterns arises. There is a weakening of the social conventions that traditionally built the life trajectories of individuals, which were based on a rigid distinction between male and female roles, 
with the designation of financial responsibilities to men and emotional tasks to women.

The results of this research also pointed out striking differences in the expectations of individuals from different generations regarding love life. Among the older generation people, it could be noticed that there was hope that marriage would last forever in association with the indissolubility of marriage provided by the social standards of the time.

Mygeneration, I guess, is the one of prince charming, that kisses the princess and she wakes up, you know? And then live happily ever after (Francisca, 65 years old, separated).

I've always imagined a marriage was forever. I was in love when I married, wanted so badly to be married that we are together until today (Norberto, 65 years old, married).

Precisely because there was an expectation of eternal marriage, divorce cases were commonly experienced by the respondents of this generation as something unexpected. A separation revealed the unpredictability of destinies and generated, within individuals, the need to find new parameters to structure their lives. The deinstitutionalization of a rigid pattern of life trajectory, as reflected in the speeches of some of our interviewees was at stake:

Ah, lexpected that my marriage would last forever, yes, I did... lexpected. But after some time, the situation came to a point that it was no longer possible to stay together. Then, we decided that it was better for us to separate, each one of us heading in a different direction (Sérgio, 69 years old, married for the $2^{\text {nd }}$ time).

We decided to separate. We were probably one of the first couples, Therewasn'teven divorce. Divorcestarted at that time. We were one of the first couples to get divorced, which is another problem. We were not even prepared to get married, let alone get divorced. The society... You could only be considered a happy person ifyou were married, if you had a family.... If you weren't, you were like some kind of criminal, or outcast or something. Separated... It as very rigid (Elias, 65 years old, separated).

Then, when this whole thing happened (the separation), I was literally with no air. Then I felt terrible, discovering how cruel the world could be. How am I going to do this without my husband by my side? How am I going to grow up? What now?...is there this side of life? This whole idea of being alone? How is it? With 3 kids? What is this like? Nobody taught me. There is no school for that, right? I felt completely unprepared. I was never prepared for separation. Because of my upbringing and also because my marriage was good. It wasn't perfect, but it was good (Francisca, 65 years old, separated).

The social pattern that instituted eternity to marital relationships influenced both the life trajectories of individuals and the way they conceived family. Paths of life were designed for them to live together with their partner forever, raising their children and growing old together. Then the woman would fulfill her role as "mother-wife-housewife" and the man would protect and provide for his family.

Exactly because we believe in the durability of marriage, a kind of family, "the happy family" (Singly, 2007), was configured, in which the financial dependence of women in relation to their husbands, and the inequality of power between them was not a problem. In this conception, the plans to start a family usually started with wedding plans. In other words, the couple founded the family.

The advent of divorce may be considered an important turning point for rupturing with life paths and family patterns established so far. References linked both to the family and to the structure of social male and female roles were questioned. The way power was distributed inside the family - women were economically dependent on their husbands - leading men and women to the need of a search for their autonomy and financial independence was questioned as well. Besides, once marriage was the legal way to socially start a family inside that context, according to Segalen (2008), divorce then, destabilized a concept of a"couple-centered"family, in other words, founded on a stable marital nucleus formation.

It is important to highlight that the advent of divorce happened within a scenario marked by several other major changes. It was a time of escalating values such as an autonomy and emancipation of the individual within society, of emphasis on egalitarianism and claim for individuality in relationships. It was a time of education for women, their march towards the labor market and financial independence, which certainly attacked the social pattern of "housewife-woman" vs. "breadwinner-men". Furthermore, an increase in life expectancy and advances in medicine and other sciences have brought new expectations to the life of a 
couple (Jablonski, 1998; Lash, 1991; Sarti, 1995; Segalen, 2008; Singly, 2007; Rocha-Coutinho, 1994).

Within this context experienced by interviewees of the older generation, evidence of changes were already seen, which led to the individualization of society and the family, and no standardizing of life trajectories for both men and women (Cavalli, 2003). It was the beginning of a new reality. "Naturalness", which corresponded to certain standards of life course and family, signaling a separation from institutions and opening to penetration of individualistic values into society, was being questioned then. A change in the social bond, which, henceforth, would provide for individuals belonging to society, although those would be free to manipulate their destinies and to be "themselves" as seen in the speech of Gilda, was at stake:

One must be in love to get married, right?... I would never get married to anyone, getting married for the sake of it, I never wanted. I'd rather be single. Most people, many people, get married simply not to be single. But I never wanted that. Forme, before getting married, I would have to like my partner a lot. And he would have to be a really nice person. If I have to choose anyone, I'd rather be alone (Gilda, 63 years old, single).

A claim for love in marriage may be understood as an attempt of opposition to the ideal of marriage as a social pattern for people to follow automatically. Passionate love, a feeling to be revealed, is related to the assertion of an authentic "I" in the marital relationship (Kaufmann, 2007a; Magalhães \& Féres-Carneiro, 2003). Finding a reason to get married being in love is having an essentially personal reason to do so, contrary to making the decision of getting married due to a social model in which people did not have the chance to reflect over their desires and to choose their own destinies. That reflects a change in the logical-social bond, in which the more individualism becomes stronger within society values, the greater the possibilities to choose among individuals.

The research evidenced that, unlike the interviewed people of the older generation, the younger respondents do not believe much that loving relationships endure. They think, instead, that they are easily breakable, as observed in the following excerpts from the interviews:

... I'm not sure I believe in long-term relationships. I really don't know. Nowadays, looking around, I realize that people stay together 10 or 15 years and then separate, with very few exceptions. And these exceptions are, many times, pure hypocrisy, couples that don't like each other anymore, you know? They are couples that don't like each other anymore and only stay together because of the pressure of society, because they are going to be judged, you know... (Lígia, 33 years old, single).

I don't know if it is in Rio de Janeiro that things happen this way, but people are very... stay together, get married, get divorced... I think it's because I know few people nowadays that really stay together for the rest of their lives... . My parents got married and, after 13 years, got divorced... and I thought they were better off separated than together. You know? (Rafaela, 34 years old, single).

I think I have a little difficulty with these contemporary values, and l already know that nothing lasts forever, you know? So I have some difficulty imagining that I'll be married to the same woman forever... . I don't know... . I know everything will end. Love relationships will end (Rodrigo, 32 years old, single).

There are, among the people interviewed, the ones from a younger generation, a demand for individual freedom in relationships, freedom to do what they want and to develop their individuality, as stated below:

Freedom. A person's individual freedom. People have their own things, things that are only theirs, you know? I have things that are my own. I can't ask someone to give this up or the other way around, got it? (Flávio, 31 years old, single).

... I love traveling alone. I'm that kind of person who will put their backpack on their back and go away... to spend the weekend... . As I am, many times, dating, this is not a nice thing and people don't always accept it, you know? ... I really likeyou, but the world is really cool. There are too many things happening. I go out, I travel (Carla, 32 years old, single).

Maybe this is why, when in a relationship, I'm not so attached to the other person. I believe people must have their individualities. I don't know... (Rafaela, 34 years old, single).

The claim for individuality in relationships is explained by the belief that the loving bond could jeopardize personal identity. In fact, in some forms of marital relationship in which it is expected that each spouse fulfill social established roles, individualities were disguised by statutory masks. However, in the present scenario, where institutions are less appreciated, freedom 
becomes an essential ingredient in the chemistry of the couple. As stated by Kaufmann (2007b), Magalhães and Féres-Carneiro (2003) and Singly (2000), there is, nowadays, the expectation that individuals will discover their "authentic selves" in a relationship between two partners, which would be incompatible with the curtailment of individualities.

The instability of love relationships do great damage to the standardizing of a life trajectory centered on the family and shakes the basis of a concept of family in which the marriage of the couple was expected to last for their entire lives. After all, as Segalen (2008) states, up to a few decades ago, marriage was the legal way to start a family; besides, it must be emphasized that there existed an idea of marriage as a stable and long lasting relationship. Nowadays, people of this generation do not believe in the resistance and endurance of love relationships, which reinforces the idea of an person being the center of their path, and moves "the children", who can easily be the result of individual projects, into the center of the concept of family.

\section{Final Considerations}

The results of this study indicated that there has been no standardization of life trajectories, resulting from the individualization of society, which reflects directly on the fact that the way of starting a family enters people's life paths. Different ways of conceiving a family have emerged in the interviews. For older people, a family has a stable couple at its core. For younger people, the center of the family is the children. In these two ways of conceiving the family the emphasis given to marital ties or to filiation ties for what starting a family represents is at stake.

Although these possibilities of generalization results are limited regarding the reduced number of participants in the survey, they contribute to the understanding of how life paths of individuals and family concepts respond to present socio - cultural changes. In a society marked by a patriarchal culture in which blood links, kinship and friendship are so important, as they are in the Brazilian society, the appreciation of filiation bonds within the family concepts of the younger individuals, the vulnerability of marital bonds, as well as the lowering of the asymmetries of the kind indicate a deep transformation in the traditional ways of relationships. People, both men and women, have the chance to reinvent themselves, to follow less established paths, but in order to do so, they lose the stability of old references. Bond relationships among families become more fluid and unstable, and the rise of the filiation value is favored.

\section{References}

Attias-Donfut, C., Lapierre, N., \& Segalen, M. (2002). Le nouvel esprit de famille. Paris: Éditions Odile Jacob.

Bauman, Z. (2008). A sociedade individualizada: vidas contadas e histórias vividas. Rio de Janeiro: Jorge Zahar.

Carvalho, M. C. B. (Org.). (1995). A família contemporânea em debate. São Paulo: Cortez.

Cavalli, S. (2003). Le parcours de vie: entre institutionnalisation et individualisation. In S. Cavalli, J. P. Franfnière (Eds.), L'avenir:attentes, projets, (dés)illusions, ouvertures. Lausanne: Editions Réalités Sociales. Consulté le Juillet 29, 2010, disponible <http://cig. unige.ch/institution/team/cavalli/ staff_sc_avenir_05042003.pdf>.

Costa, J. F. (1989). Ordem médica e norma familiar (3a ed.). Rio de Janeiro: Graal.

Féres-Carneiro, T. (Org.). (2005). Família e casal: efeitos da contemporaneidade. Rio de Janeiro: PUC-Rio.

Féres-Carneiro, T., \& Ziviani, C. (2009). Conjugalidades contemporâneas: um estudo sobre os múltiplos arranjos amorosos da atualidade. In T. Féres-Carneiro (Org.), Casal e família: permanências e rupturas (pp.83-107). São Paulo: Casa do Psicólogo.

Féres-Carneiro, T., Ziviani, C., \& Magalhães, A. S. (2011). Arranjos amorosos contemporâneos: sexualidade, fidelidade e dinheiro na vivência da conjugalidade. In: T. Féres-Carneiro (Org.), Família e casal: efeitos da contemporaneidade (pp.43-59). Rio de Janeiro: PUC-Rio.

Figueira, S. A. (1987). O moderno e o arcaico na nova família brasileira: notas sobre a dimensão invisível da mudança social. In S. A. Figueira. Uma nova família? O moderno e o arcaico na família de classe média brasileira (pp.11-30). Rio de Janeiro: Jorge Zahar.

Giddens, A. (2003). Mundo em descontrole: o que a globalização está fazendo de nós ( $3^{\mathrm{a}}$ ed.). Rio de Janeiro: Record.

Hall, S. (2001). A identidade cultural na pós-modernidade. Rio de Janeiro: DP\&A.

Heilborn, M. L. (2004). Dois é par: gênero e identidade sexual em contexto igualitário. Rio de Janeiro: Garamond.

Instituto Brasileiro de Geografia e Estatística. Banco de dados. Rio de Janeiro: Autor. Recuperado junho 15, 2010, disponível em <http://www.ibge.gov.br/seculoxx/ arquivos_xls/palavra_chave/populacao/registro_ civil.shtm>. 
Instituto de Pesquisa Econômica Aplicada. Banco de dados. Brasília: Autor. Recuperado em novembro 14, 2010, disponível em <www.ipea.gov.br>.

Jablonski, B. (1998). Até que a vida nos separe: a crise do casamento contemporâneo ( $2^{\mathrm{a}}$ ed.). Rio de Janeiro: Agir.

Jablonski, B. (2009). Atitudes e expectativas de jovens solteiros frente à família e ao casamento: duas décadas de estudos. In T. Féres-Carneiro (Org.), Casale família:permanências e rupturas (pp.109-134). São Paulo: Casa do Psicólogo.

Jablonski, B. (2010). A divisão de tarefas domésticas entre homens e mulheres no cotidiano do casamento. Psicologia: Ciência e Profissão, 30(2), 262-275.

Kaufmann, J. C. (2007a). Sociologie du couple (4a ed.). Paris: PUF.

Kaufmann, J. C. (2007b). L'entretien compréhensif. Paris: Armand Colin

Lash, C. (1991). Refúgio num mundo sem coração. A família: santuário ou instituição sitiada? Rio de Janeiro: Paz e Terra.

Magalhães, A. S., \& Feres-Carneiro, T. (2003). Conjugalidade e subjetividades contemporâneas: o parceiro como instrumento de legitimação do "eu". Encontro Mundial dos Estados Gerais da Psicanálise, Rio de Janeiro, RJ, Brasil, 2. Recuperado em junho 15, 2010, disponível em <http://www.estadosgerais.org/mundial.rj>

Maluf, M., \& Mott, M. L. (2008). Recônditos do mundo feminino. In F. A. Novais \& N. Sevcenko (Orgs.), História da vida privada no Brasil 3 - república: da belle époque à era do rádio. São Paulo: Companhia das Letras.

Mannheim, K. (1982). A questão das gerações. In M. M. Foracchi (Org.), Sociologia. São Paulo: Ática.
Rocha-Coutinho, M. L. (1994). Tecendo por trás dos panos: a mulher brasileira nas relações familiares. Rio de Janeiro: Rocco.

Rocha-Coutinho, M. L. (1998). A análise do discurso em psicologia: algumas questões, problemas e limites. In L. Souza, M. F. Quintal de Freitas \& M. M. P. Rodrigues (Orgs.), Psicologia: reflexões (im)pertinentes. São Paulo: Casa do Psicólogo.

Rocha-Coutinho, M. L. (2005). O papel de homens e mulheres na família: podemos falar em reestruturação? Psicologia Clínica, 15(2), 93-108.

Sarti, C. A. (1995). Família e individualidade: um problema moderno. In M. C. B. Carvalho (Org.), A família contemporânea em debate ( $2^{\mathrm{a}}$ ed.). São Paulo: Cortez.

Segalen, M. (2008). Sociologie de la famille (6 ed.). Paris: Armand Colin.

Singly, F. (2000). Libres ensemble: l'individualisme dans la vie commune. Paris: Nathan.

Singly, F. (2007). Sociologia da família contemporânea. Rio de Janeiro: FGV.

Vaitsman, J. (1994). Flexíveis e plurais: identidade, casamento e família em circunstâncias pós-modernas. Rio de Janeiro: Rocco.

Wagner, A. (Coord.). (2002). Família em cena: tramas, dramas e transformações. Petrópolis: Vozes.

Received on: 26/7/2011

Final version on: $3 / 4 / 2012$

Approved on: 24/4/2012 
